\title{
A Comparison of Chemical Composition between Diploids and Triploids of "Ginbuna" Carassius auratus langsdorfi
}

\author{
Keijiro SeZAKI, ${ }^{* 1}$ Shugo Watabe, ${ }^{* 2}$ and Kanehisa HaShimoto*2 \\ (Received May 24, 1982)
}

\begin{abstract}
The diploid and triploid populations of "ginbuna" Carassius auratus langsdorfi were compared in terms of several consituents in the muscle and blood. The muscles of both populations did not differ clearly from each other in the proximate and protein compositions. No significant differences were found in the hematocrit value and hemoglobin level of the blood either.

Activities of some erythrocyte glycolytic enzymes such as hexokinase and phosphofructokinase were 1.26-1.35 times higher in the triploid than in the diploid, on a per cell basis. However, the activities of each enzyme matched well each other on a unit blood volume basis. This, together with other results, suggested that a regulation system is retained in the triploid so that its metabolic rate is controlled at the diploid level.
\end{abstract}

Diploids and triploids (even tetraploids in some cases) of "ginbuna" Carassius auratus langsdorfi distribute sympatrically in many river systems of Japan. ${ }^{1-8)}$ Rivers or lakes where either di- or triploids exclusively occur, are also known. As reported previously, diploid and triploid populations of ginbuna differ from each other in both erythrocytic size and muscle myogen electropherogram. This suggests that both populations may differ from each other in other aspects as well. Under these backgrounds, the present study was made to compare muscle and blood constituents between the diploid and triploid populations of ginbuna.

\section{Materials and Methods}

\section{Materials}

Specimens of ginbuna Carassius auratus langsdorfi were captured at Kaname River, Kanagawa Prefecture, and Naka River, Shizuoka Prefecture. They were transported alive to the Laboratory of Marine Biochemistry, The Univ. of Tokyo, and immediately a few drops of blood were collected for determining their ploidy by heart puncture as reported previously.1,4) Then, the di- and triploids were separately reared in tanks several days to weeks until used. Table 1 shows the details of the ginbuna specimens assayed.

\section{Analytical Methods}

\section{Proximate Composition of Muscle}

The dorsal muscles from the 12 specimens of each ploidy were excised, combined, and analyzed for proximate composition as usual. The average values of duplicate determinations are given in "Results."

\section{Protein Composition of Muscle}

The dorsal muscles of the 3 specimens of each ploidy were similarly excised, combined, and analyzed for protein composition by the procedures reported previously. ${ }^{5)}$ In addition, portions of the sarcoplasmic and myofibrillar fractions thus obtained were analyzed by SDS-gel electrophoresis. ${ }^{6)}$

\section{Hematological Examination}

Portions of the respective blood specimens of each ploidy were determined for hemoglobin concentration by the cyanmethemoglobin method, for erythrocyte count with a Thoma hemocytometer, and for hematocrit value by the microhematocrit tube method.") Mean corpuscular volume (MCV), mean corpuscular hemoglobin (MCH) and mean corpuscular hemoglobin concentration (MCHC) were calculated from those data according to WINTROBE. ${ }^{\text {7) }}$

\section{Assay of Enzyme Activities}

From portions of the heparinized blood of

*1 Enoshima Aquarium, Katasekaigan, Fujisawa, Kanagawa 251, Japan（濑绮啓次郎：江／島水族刢）。

*2 Lab. of Marine Biochem., Fac. of Agr., The Univ. of Tokyo, Bunkyo, Tokyo 113, Japan (渡部終五 - 俩本 周久: 東京大学農学部). 


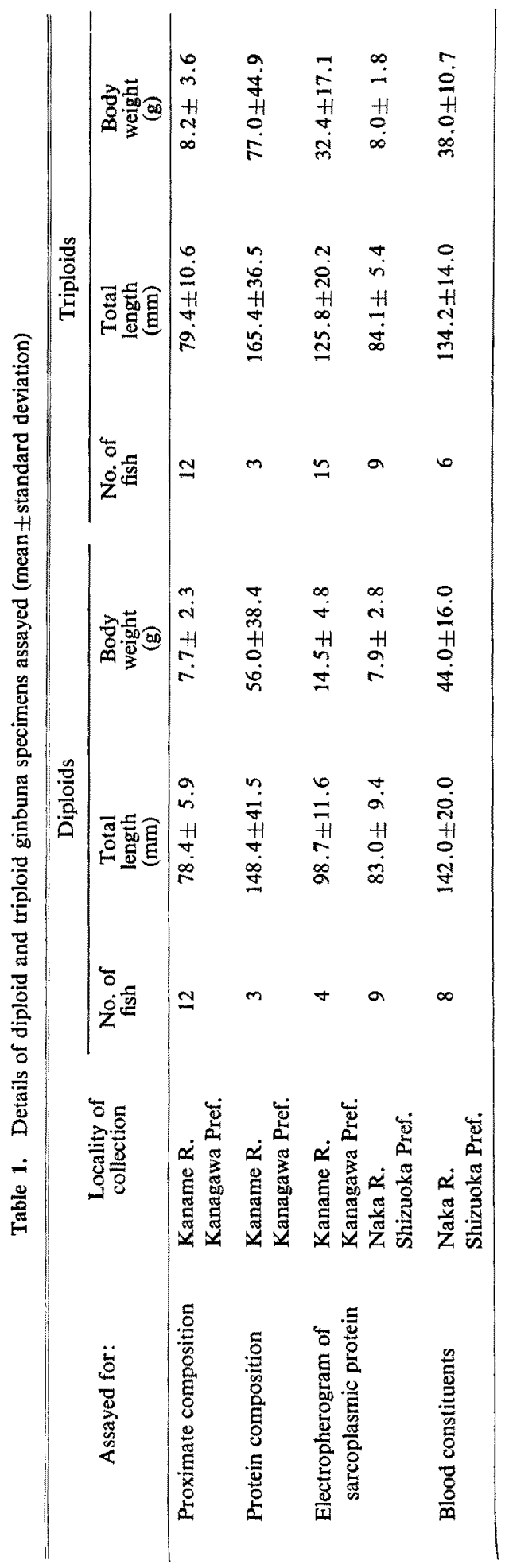


each ploidy were prepared the hemolyzates as usual. The hemolyzates were assayed for the activities of some glycolytic enzymes: hexokinase (HK, EC: 2.7.1.1), phosphofructokinase (PFK, EC: 2.7.1.11), and pyruvate kinase (PK, EC: 2.7.1.40), essentially according to JosHI and JAGNNATHAN, ${ }^{8)}$ Ling et al., ${ }^{9)}$ and Valentine and TANAKA, ${ }^{10)}$ respectively.

\section{Results}

The dorsal muscles of the di- and triploid specimens showed essentially the same proximate and protein compositions, as seen in Tables 2 and 3. The myofibrillar fractions from both populations revealed indistinguishable SDS-gel electropherograms. However, this was not true in their sarcoplasmic fractions (Fig. 1). The diploids showed two bands $\mathbf{A}$ and $\mathbf{B}$, in the region of around 70,000 dalton, whereas the triploids showed the same two bands, and three bands as designated $\mathbf{A}_{1}, \mathbf{A}_{2}$ and $\mathbf{B}$, or $\mathbf{A}, \mathbf{B}_{1}$ and $\mathbf{B}_{2}$, depending upon the individuals.

Frequencies of those patterns in the 28 speci-

Table 2. Proximate compositions of dorsal muscle of di- and triploid ginbuna ( $\%$ )

\begin{tabular}{cccccc}
\hline \hline Ploidy & Moisture & Crude protein & Crude fat & Crude ash & Total \\
\hline $2 \mathrm{n}$ & 79.64 & 18.15 & 0.70 & 1.17 & 99.66 \\
$3 \mathrm{n}$ & 80.25 & 18.38 & 0.58 & 1.18 & 100.34 \\
\hline
\end{tabular}

Table 3. Protein compositions of dorsal muscle of di- and triploid ginbuna ( $\mathrm{mg} \mathrm{N} / \mathrm{g}$ muscle)

\begin{tabular}{ccccccc}
\hline \multirow{2}{*}{ Ploidy } & \multirow{2}{*}{ Non-protein N } & \multicolumn{4}{c}{ Protein N* } \\
\cline { 3 - 7 } & & Sarcoplasmic & Myofibrillar & Alkali-soluble & Stroma & Total \\
\hline \multirow{2}{*}{$2 \mathrm{n}$} & 3.70 & 7.04 & 19.73 & 0.73 & 0.53 & 28.03 \\
& & $(25.0)$ & $(70.4)$ & $(2.6)$ & $(1.9)$ & $(100)$ \\
$3 \mathrm{n}$ & 3.82 & 7.89 & 19.58 & 0.51 & 0.63 & 28.61 \\
& & $(27.6)$ & $(68.4)$ & $(1.8)$ & $(2.2)$ & $(100)$ \\
\hline
\end{tabular}

* Numbers in parenthesis represent percentage distribution

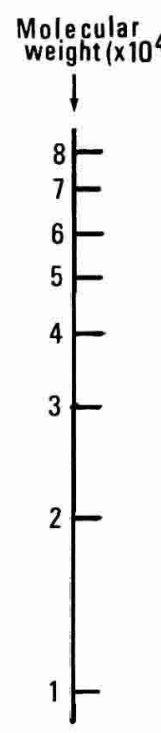

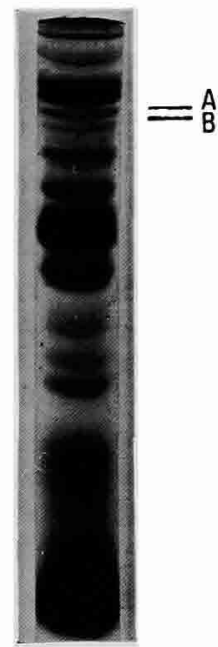

$A B$

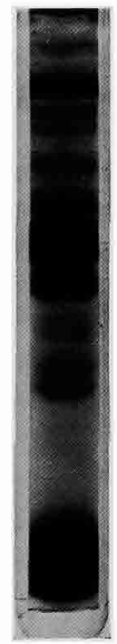

$A_{1} A_{2} B$
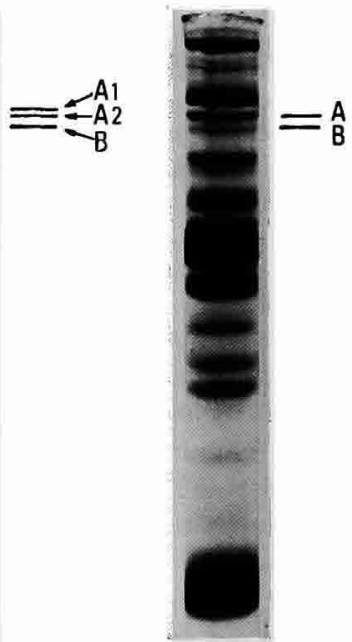

$A B$

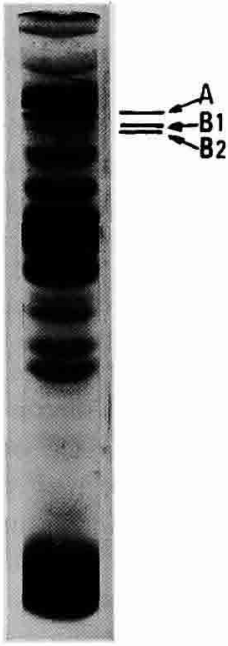

$A B_{1} B_{2}$

Diploid Triploid

Fig. 1. SDS-gel electrophoresis of sarcoplasmic protein fractions from di- and triploid ginbuna. 
Table 4. Frequencies of SDS-gel electropherograms of sarcoplasmic protein in di- and triploid ginbuna

\begin{tabular}{lccrcc} 
& \multicolumn{4}{c}{ Electropherogram } \\
\cline { 2 - 5 } $\begin{array}{l}\text { Locality of } \\
\text { collection }\end{array}$ & Diploid & & \multicolumn{2}{c}{ Triploids } \\
\cline { 2 - 6 } & $\mathrm{AB}$ & & $\mathrm{A}_{1} \mathrm{~A}_{2} \mathrm{~B}$ & $\mathrm{AB}$ & $\mathrm{AB}_{1} \mathrm{~B}_{2}$ \\
\hline $\begin{array}{l}\text { Kaname R. } \\
\text { Naka R. }\end{array}$ & 4 & 5 & 16 & 3 \\
& 9 & & 9 & -
\end{tabular}

mens collected from Kaname River and the 18 specimens from Naka River are summarized in Table 4. All diploid specimens from both rivers showed one and the same electrophoretic pattern $A B$. The triploids from Kaname River showed three patterns as designated $A_{1} A_{2} B, A B$ and $A B_{1} B_{2}$, whose frequencies were 5,16 and 3 , respectively. On the other hand, all the specimens from Naka River showed pattern $A B$, irrespective of ploidy.

The results of hematological examination are summarized in Table 5. The triploids showed smaller erythrocytic count, larger $\mathrm{MCV}$ and $\mathrm{MCH}$ than did the diploids. However, no significant differences were recognized between both populations, in hemoglobin concentration, hematocrit value, and $\mathrm{MCHC}$.

As Table 6 shows, PK activity per $10^{10}$ erythrocytes was remarkably higher in the triploid than in the diploid, the ratio being 1.68. So were the cases with $\mathrm{HK}$ and PFK the ratios being 1.26 and 1.35 , respectively. The activity ratios (triploid/diploid) for the two latter enzymes were near unity when calculated on gram hemoglobin or milliliter blood basis.

\section{Discussion}

As reported before, ${ }^{2,3)}$ the starch gel electropherogram of sarcoplasmic protein is useful in the determination of ploidy in ginbuna. On polyacrylamide gel electrophoresis, the sarcoplasmic protein of the triploid showed the three patterns (Fig. 1). One of them was not distinguishable from that of the diploid. Myofibrillar proteins of the diploid and triploid did not differ from each other electrophoretically. The proximate and protein compositions of muscle were hardly distinguishable from each other either.

The size of erythrocyte tends to become smaller as the animal goes up the evolutionary ladder. ${ }^{11)}$ The erythrocyte size was larger and the number

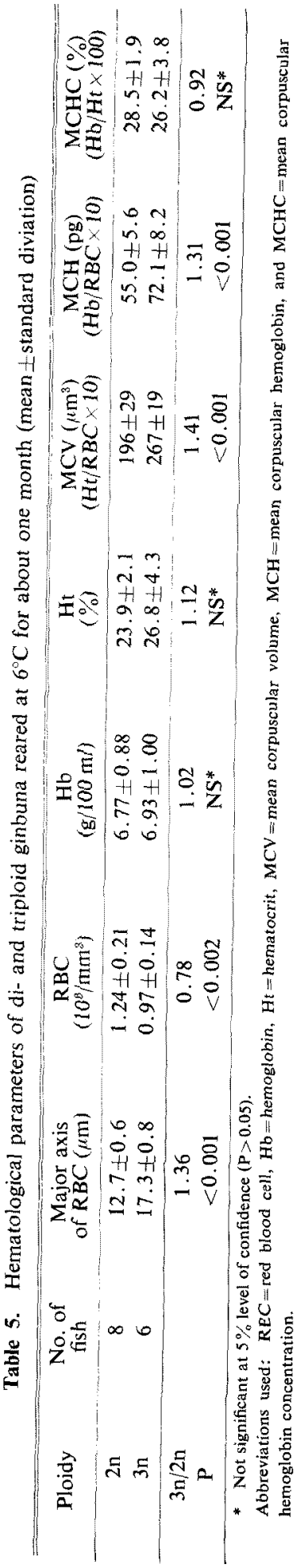


Table 6. Comparison of activities of three erythrocyte enzymes between di- and triploid ginbuna (mean \pm standard deviation)

\begin{tabular}{ccccc}
\hline Enzyme & IU per: & Diploid & Triploid & Triploid/Diploid \\
\hline Hexokinase & $10^{10} \mathrm{cells}$ & $0.95 \pm 0.30$ & $1.20 \pm 0.41$ & 1.26 \\
& gram Hb & $1.71 \pm 0.48$ & $1.70 \pm 0.51$ & 0.99 \\
Phosphofructokinase & ml blood & $0.12 \pm 0.03$ & $0.12 \pm 0.05$ & 1.00 \\
& $10^{10} \mathrm{cells}$ & $5.03 \pm 1.07$ & $6.79 \pm 1.85$ & 1.35 \\
Pram Hb & $9.19 \pm 1.95$ & $9.63 \pm 2.65$ & 1.05 \\
Pyruvate kinase & ml blood & $0.63 \pm 0.22$ & $0.65 \pm 0.11$ & 1.03 \\
& $10^{10} \mathrm{cells}$ & $78.4 \pm 47.0$ & $132 \pm 26.3$ & 1.68 \\
& gram Hb & $141 \pm 79.7$ & $186 \pm 28.3$ & 1.32 \\
& ml blood & $9.40 \pm 5.12$ & $12.7 \pm 2.70$ & 1.35 \\
\hline
\end{tabular}

less in the triploid than in the diploid (Table 5). Both populations showed comparable hematocrit values and hemoglobin concentrations, resulting in another similarity in MCHC. Such a phenomenon has also been observed in polyploids of chicken $^{12)}$ and salamander, ${ }^{13)}$

HK, PFK, and PK activities per erythrocyte were clearly higher in the triploid than in the diploid (Table 6). However, the activities of each enzyme calculated per unit weight of hemoglobin or unit blood volume matched well between both populations of ginbuna. Thus, it can be concluded that the total activity of each enzyme in the triploid is controlled at the same level as in the diploid, demonstrating the presence of another regulation here. In this connection, it was noted that the activities of the three erythrocyte enzymes of ginbuna are much higher than those of human enzymes: $3-5$ times higher in HK, 2-5 times in PFK, and 20-30 times in PK.

ScHMIDTKE et al. proposed a hypothesis that phylogenetically tetraploid cyprinid fishes regulate various functions at the diploid level, ${ }^{143}$ while this is not true for phylogenetically tetraploid clupeoid and salmonid fishes. ${ }^{15}$ ) Their hypothesis is based on cellular sizes of those fishes, i.e., whether the cellular size of the "tetraploid" is larger than the diploid or not. Comparisons by the methods as adopted in the present study seem to be necessary in the cases of those fishes.

\section{Acknowledgements}

We express our sincere thanks to Professor $\mathrm{H}$. OzaKI, Tokyo University of Fisheries, and to Dr. Y. Hrrosaki, Enoshima Aquarium, for their continuous interest and encouragement. The expenses of the present work were partly supported by a Grant-in-Aid from the Ministry of Educa- tion, Science and Culture.

\section{References}

1) K. Sezaki, H. Kobayasi, and M. Nakamura: Japan. J. Ichthyol., 24, 135-140 (1977).

2) S.-M. Liu, K. Sezaki, K. Hashimoto, H. KobaYasi, and M. Nakamura: Bull. Japan. Soc. Sci. Fish., 44, 601-606 (1978).

3) S.-M. Liu, K. Sezaki, M. Nakamura, and K. Hashnoto: Bull. Japan. Soc. Sci. Fish., 46, 413-418 (1980).

4) K. Sezaki and H. Kobayasi: Bull. Japan. Soc. Sci. Fish., 44, 851-854 (1978).

5) K. Hashimoto, S. Watabe, M. Kono, and K. ShIro: Bull. Japan. Soc. Sci. Fish., 45, 14351441 (1979).

6) K. Weber and M. Osborn: J. Biol. Chem., 244, 4406-4412 (1969).

7) M. M. Wintrone: Clinical Hematology, 7th ed., Lea \& Febiger, Philadelphia, 1974, pp. 109119.

8) M. D. Joshi and V. JAGNNATHAN: in "Methods in Enzymology" (ed. by W. A. Wood), vol. 9, Acad. Press, New York, 1966, pp. 371-375.

9) K. H. King, V. Paetkau, F. Marcus, and H. A. LARDY: in "Methods in Enzymology" (ed. by W. A. Woon), Vol. 9, Acad. Press, New York, 1966, pp. 425-429.

10) W. N. Valentine and K. R. TANaKa: in "Methods in Enzymology" (ed. by W. A. Woon), Vol. 9, Acad. Press, New York, 1966, pp. 468473.

11) M. M. Wintrobe: Folia Hematol., 51, 32-49 (1933).

12) F. ABDELL-HAMEd: Science, 178, 864-865 (1972).

13) P. Deparis, J.-C. Beetschen, and A. Jaylet: Comp. Biochem. Physiol., 50A, 263-266 (1975).

14) J. SCHMmtKe and W. ENGEL: Biochem. Genet., 13, 45-51 (1975).

15) J. SchmidtKe, N. B. AtKIN, and W. EnGel: Biochem. Genet., 13, 301-309 (1975). 